\title{
Below-ground resources limit seedling growth in forest understories but do not alter biomass distribution
}

\author{
José-Luis MACHADO ${ }^{\mathrm{a}, \mathrm{b} *}$, Michael B. WALTERS ${ }^{\mathrm{a}, \mathrm{c}}$ and Peter B. REICH ${ }^{\mathrm{a}}$ \\ a Department of Forest Resources, University of Minnesota, 1530 Cleveland Av. North, St. Paul, MN 55108, USA \\ ${ }^{b}$ Current address: Department of Biology, Swarthmore College, Swarthmore, PA 19081, USA \\ ${ }^{c}$ Current address: Department of Forestry, Michigan State University, 126 Natural Resources Building, East Lansing, MI 48824, USA
}

(Received 20 August 2001; accepted 10 May 2002)

\begin{abstract}
We examined the long-term growth, morphology, biomass distribution, and survival response of seedlings of five conifer species varying widely in shade tolerance to an increase in soil resources in shaded forest understories in northern Wisconsin, USA. In a 4-year experiment, trenching treatment was used to increase soil resource supply to 1-year old seedlings planted across a range of low light microenvironments. Specifically we asked: (1) does an increase in soil resources alter whole-plant growth, biomass distribution patterns, and survival in lowlight, and (2) do species differ in their responses to increasing soil resources? Increased soil resource availability increased height $(+11 \%$ on average) and dry mass $(+23 \%$ on average) of all species regardless of light availability. However, there was no evidence that trenching affected biomass distribution for any species, as has been previously reported. Survivorship after four years was positively related to the species' reported shade tolerance ranking and was unaltered by trenching. We concluded that soil resource availability (supply-demand) can limit tree seedling growth in deeply shaded forest understories, but that increased resource availability of the magnitude caused by trenching does not favor tolerant rather than intolerant species, or vice-versa.
\end{abstract}

long-term / trenching / northern Wisconsin / conifer species / field-grown seedlings

Résumé - Les ressources du sol limitent la croissance des semis se développant sous couvert forestier, mais ne modifient pas la distribution de leur biomasse. Nous avons examiné l'effet à long terme de l'accroissement des ressources du sol sur la croissance, la distribution de la biomasse et la survie d'espèces dont la tolérance à l'ombre est très différente, dans le sous-étage de forêts du Nord Wisconsin aux USA. On a conduit sur 4 ans une expérimentation consistant à apporter un supplément de ressources à des semis de 1 an installés dans toute une gamme de micro-environnements peu éclairés. Les questions posées étaient : (1) Est-ce que un accroissement des ressources du sol modifie la croissance totale du plant, le modèle de distribution de la biomasse et la survie, sous un faible éclairement ? (2) Est-ce que les espèces réagissent différemment à l'accroissement des ressources? L'augmentation des disponibilités en ressources se traduit par un accroissement de la hauteur (en moyenne $+11 \%$ ) et de la matière sèche (en moyenne $+23 \%$ ) pour toutes les espèces et quel que soit l'éclairement. Cependant, aucun effet n'a pu être mis en évidence sur la distribution de la biomasse des différentes espèces contrairement à ce qui a été dit auparavant. La survie, après 4 ans, est liée positivement au niveau de la tolérance à l'ombre des espèces. Elle n'a pas été modifiée par le traitement. Nous concluons que le niveau des disponibilités en ressources peut limiter la croissance des plantes dans les sous-étages à faible éclairement, mais qu'un apport de l'ordre de celui adopté dans cette expérimentation, ne favorise pas plus les espèces tolérantes que celles qui ne le sont pas.

long terme / tranchées / nord-Wisconsin / espèces conifères / plants sur le terrain

\section{INTRODUCTION}

Light has frequently been observed to be the main factor limiting plant growth in deeply shaded understories [5, 33, 46]. However, the multiple resource limitation theory [8, 16, $17,42]$ and trenching, fertilization, and gradient experiments suggest that water and/or nutrients along with light might colimit growth in forest understories [9, 19, 27, 39, 40, 47, 49]. Neither fertilization nor trenching experiments have provided a clear understanding of how nutrients, and water interact together with light to affect growth, biomass distribution patterns and survival of seedlings [6]. Many such studies have been performed over short time intervals (often less than a year), and have lacked whole-plant measurements of mass and morphology that included root systems.

A recent review of trenching experiments suggests that for understory plants growing in moist, nutrient rich sites, light may more strongly limit growth than do soil resources whereas, on infertile and/or drier soils, growth may be more strongly limited by soil resources than by light [10]. In addition, 
greenhouse studies have shown that tree seedlings' abilities to respond to increased soil resources diminish as light levels decrease $[4,49,50]$. Finally, we suggest that wide variation among studies [10] may, in part, be due to differences among species in their ability to respond to increased soil resources in deep shade $[49,50]$. Collectively, these findings and ideas suggest that the combination of variation among species in resource tolerance, and among habitats in light and nutrient supply is likely to result in complex patterns and interactions.

Tree species differ markedly in their ability to tolerate deeply shaded forest understories. This ability, although coined shade tolerance, may be largely due to collections of traits that maximize survival via the efficient use of limiting resources in forest understories. Such resources may include both light and soil resources [26, 27, 48]. In a controlled experiment, shade intolerant species survived better in deep shade under higher than lower nutrient availability [50]. In contrast, shade tolerant species, which survived better than the intolerants in any case, were unaffected by variation in nutrient supply [50]. Thus, if species differ in their responses to soil resources in low-light forest understories, then it is likely that they will differ to the greatest degree for species comprising a broad gradient of reported shade tolerances.

Given the above-mentioned sources of variability, and our limited understanding therein, it is difficult to predict trends in growth, biomass distribution (defined here, as the mean relative fraction of biomass found in the different plant components at harvest time) and survival of plants with different shade tolerance classification. Nevertheless, based on prior findings, we can propose the following three hypotheses. First, consistent with the multiple resource limitation hypothesis [8, $16,17,42]$, we predict that trenching will generally have a positive effect on whole-plant growth and survival and will increase the proportion of leaves and stems as a fraction of whole plant mass. The second hypothesis proposes that all species response will be influenced by light, such as all species will respond more to trenching in higher light as in lower light. Finally, the third hypothesis proposes that the response will differ among species in relation to shade tolerance, such that species that are more shade tolerant will respond more to trenching than shade intolerant species. This is based on the idea that shade intolerant species will be so limited by deep shade that they will be unable to respond to changes in soil resources.

To address these hypotheses we examined the long-term responses of seedlings of five conifer species (Pinus banksiana Lamb., Pinus resinosa Ait., Pinus strobus L., Picea glauca (Moench) Voss. and Abies balsamea (L.) Mill.) to an increase in soil resources from trenching in shaded (3-11\% of canopy openness) low fertility forest understories in northern Wisconsin, USA. In this long-term field study, we asked (1) does an increase in soil resources alter whole-plant growth, survival, or biomass distribution patterns in low-light environments and (2) do species differ in their responses to increased soil resources; and (3) if so, are these differences related to their shade tolerance classification.

Soil trenching in field experiments has been used for over a century to alter the availability of soil resources and to evaluate the impact of belowground competition [10]. Trenching is the process of physically isolating a group of plants by installing a barrier that prevents root ingrowth from the surrounding vegetation and removes competition from the surrounding vegetation since their extant roots are severed during the trenching [22]. Trenching increases soil resource supply to residual plants largely by reducing resource demand (i.e., reducing competition) [27]. Among soil resources altered by trenching are the availability of water and of nitrogen. Several authors have reported a two-fold increase in water [11, 12, 13], and others have shown an increase in the availability of nitrogen for different forest types ([44] for deciduous and evergreen forest in North America, [21] for spruce plantations in Europe and [41] for tropical lower montane forest in the Caribbean).

\section{METHODS}

\subsection{Sites and experimental design}

We located two sites $6 \mathrm{~km}$ apart on moderately low fertility sandy outwash soils in northern Wisconsin, USA in the summer of 1993. At site 1 , forest overstories were dominated by Quercus rubra L., Acer rubrum L. and Populus tremuloides Michx., and at site 2 by Populus tremuloides, Quercus rubra and scattered Pinus strobus L. individuals. During the four years of this experiment there was no evidence of drought in the region. Total precipitation during the growing season (May to September) was 411, 514, 465 and $388 \mathrm{~mm}$ for 1993, 1994, 1995 and 1996, respectively (North Temperate Lakes Long-Term Ecological Research weather records located less than $9 \mathrm{~km}$ from both research sites).

Across the two research sites we randomly selected 11 pairs of $5 \times$ $3.5 \mathrm{~m}$ plots ( $n=12$ and $n=10$ plots for site 1 and 2, respectively). In the spring of 1993, one plot of each pair was trenched prior to planting by digging $1-\mathrm{m}$ deep and $0.3 \mathrm{~m}$ wide trenches around the plot and lined with root restriction cloth (Landscape Fabric, St. Paul, MN, USA). This fabric allows transfer of water and gases but does not permit root penetration. In these forests, most roots exist within the top 20-cm depth [48]. Prior to planting, the existing aboveground biomass of small vegetation was hand-pulled and allowed to decay on the surface of both trenched and control plots. After planting, all plots were weeded once a year.

For each plot, percent canopy openness was measured with the LAI-2000 plant canopy analyzer (Li-Cor, Lincoln, NB, USA). These values are a good surrogate of mean daily percent photosynthetic photon flux density [32]. During August 18 and 19, 1994, one canopy openness measurement for each corner of every plot was taken when the sky was uniformly overcast or during twilight after dawn and before dusk. Measurements were averaged to account for the spatial variation of each plot. We used one LAI-2000 at the measurement point (forest understory) while another paired unit simultaneously measured open sky values in a large clear-cut that was less than $1 \mathrm{~km}$ away. We averaged the four measurements of each plot. During the four years of the experiment we did not notice mortality of any large trees in the canopy.

Soil nitrogen and moisture were measured in control and trenched plots in August 1996 by extracting six soil cores $(5 \mathrm{~cm}$ diameter $\times$ $20 \mathrm{~cm}$ deep) from each plot. These were subsequently pooled by plot. We oven-dried subsamples of the bulked soils at $105^{\circ} \mathrm{C}$ to determine soil water content. For another subsample, $2 \mathrm{M} \mathrm{KCl}$ extractions of $\mathrm{NH}_{4}$ and $\mathrm{NO}_{3}$ were made on fresh soil. $\mathrm{NH}_{4}$ and $\mathrm{NO}_{3}$ pools in the soil were measured by conversion to salicylic acid and copper cadmium reduction to nitrite, respectively, followed by calorimetric analysis (University of Minnesota, Department of Soil Science Research Analytical Laboratory). 
Table I. Light environments and soil nitrogen and water in each control and trenched plots. Canopy openness values are the mean of four measurements taken in August of 1994. Soil nitrogen and water values are single measurements taken in August of 1996, at the end of the experiment. At the bottom, for all plots ( $n=11$ for each control and trench treatments), we included the mean, standard error (S.E.) and the probability values for $t$-tests. Significant values $<0.1$ are shown in bold.

\begin{tabular}{|c|c|c|c|c|c|c|c|c|c|}
\hline \multirow[b]{2}{*}{ Site } & \multirow[b]{2}{*}{ Plot \# } & \multicolumn{2}{|c|}{$\begin{array}{c}\text { Canopy openness } \\
(\%)\end{array}$} & \multicolumn{2}{|c|}{$\begin{array}{c}\text { Soil water } \\
(\%)\end{array}$} & \multicolumn{2}{|c|}{$\begin{array}{c}\mathrm{NO}_{3}^{-} \text {pool } \\
\left(\mu \mathrm{mol} \mathrm{N} \mathrm{g}{ }^{-1} \text { soil }\right)\end{array}$} & \multicolumn{2}{|c|}{$\begin{array}{c}\mathrm{NH}_{4}^{+} \text {pool } \\
\left(\mu \mathrm{mol} \mathrm{N} \mathrm{g}{ }^{-1} \text { soil }\right)\end{array}$} \\
\hline & & Control & Trench & Control & Trench & Control & Trench & Control & Trench \\
\hline \multirow[t]{6}{*}{1} & 1 & 3.2 & 4.1 & 14.8 & 16.2 & 5.7 & 3.4 & 9.9 & 11.5 \\
\hline & 2 & 3.8 & 4.0 & 18.9 & 19.6 & 2.2 & 3.7 & 9.7 & 11.9 \\
\hline & 3 & 7.2 & 6.8 & 17.4 & 18.6 & 5.0 & 3.3 & 10.1 & 17.3 \\
\hline & 4 & 7.0 & 6.6 & 16.3 & 21.4 & 3.2 & 8.6 & 7.9 & 13.6 \\
\hline & 5 & 7.6 & 6.4 & 20.2 & 19.0 & 4.2 & 4.7 & 12.2 & 12.0 \\
\hline & 6 & 3.4 & 3.1 & 15.3 & 15.7 & 5.4 & 5.6 & 12.3 & 10.7 \\
\hline \multirow[t]{5}{*}{2} & 1 & 8.0 & 11.0 & 12.8 & 23.6 & 3.8 & 3.1 & 7.3 & 12.7 \\
\hline & 2 & 11.1 & 10.1 & 12.6 & 17.4 & 2.2 & 3.3 & 4.8 & 7.5 \\
\hline & 3 & 7.7 & 7.8 & 13.3 & 15.9 & 6.8 & 4.6 & 10.4 & 8.9 \\
\hline & 4 & 7.6 & 7.4 & 14.8 & 27.0 & 3.4 & 5.9 & 7.5 & 14.9 \\
\hline & 5 & 5.5 & 5.3 & 15.3 & 14.0 & 6.0 & 5.4 & 8.7 & 9.3 \\
\hline Mean & & 6.6 & 6.6 & 15.6 & 19.0 & 4.3 & 4.7 & 9.2 & 11.8 \\
\hline S.E. & & 0.72 & 0.74 & 0.73 & 1.15 & 0.46 & 0.49 & 0.67 & 0.84 \\
\hline Prob $>|t|$ & & \multicolumn{2}{|c|}{0.97} & \multicolumn{2}{|c|}{0.02} & \multicolumn{2}{|c|}{0.61} & \multicolumn{2}{|c|}{0.02} \\
\hline
\end{tabular}

Table II. Seedling height prior to planting and a comparison between shade tolerance rankings described in the forestry literature and the distribution of juveniles ( 0.25 to $1.5 \mathrm{~m}$ of height) along light environments in the field. Seedling height values are the mean and standard error (in parenthesis). The shade tolerance scores from field data correspond to the 10th percentile of the distribution of juveniles growing in northern Minnesota [31]. Scores are inversely related to the subjective assessments of shade tolerance rankings described by North American foresters [3]. Light data for Pinus banksiana are not available.

\begin{tabular}{|c|c|c|c|c|}
\hline \multirow[t]{2}{*}{ Species } & \multicolumn{2}{|c|}{$\begin{array}{l}\text { Seedling height prior to planting } \\
(\mathrm{cm})\end{array}$} & \multirow[t]{2}{*}{$\begin{array}{c}\text { Shade tolerance } \\
\text { scores from field data }\end{array}$} & \multirow[t]{2}{*}{$\begin{array}{l}\text { Shade tolerance } \\
\text { rankings }\end{array}$} \\
\hline & Control & Trench & & \\
\hline Abies balsamea & $10.1(0.3)$ & $9.4(0.3)$ & 2.17 & Very tolerant \\
\hline Picea glauca & $14.9(0.4)$ & $14.8(0.4)$ & 2.68 & Tolerant \\
\hline Pinus strobus & $16.2(0.3)$ & $16.3(0.3)$ & 2.91 & Intermediate \\
\hline Pinus resinosa & $15.0(0.4)$ & $13.7(0.4)$ & 10.11 & Intolerant \\
\hline Pinus banksiana & $12.7(0.3)$ & $12.6(0.3)$ & N.A. & Very intolerant \\
\hline
\end{tabular}

No significant differences among sites were found in soil nitrogen (N) pools, gravimetric soil moisture or light environments at the stand level. Trenching significantly increased $\mathrm{KCl}$ extractable $\mathrm{NH}_{4}$ pools and gravimetric moisture content, while $\mathrm{NO}_{3}$ pools and percent canopy openness did not differ between trenched and untrenched plots (Tab. I). Inorganic $\mathrm{N}$ pools are suggested to be a good measure of the soil solution concentration of $\mathrm{N}$ available for plants [43], and some authors have found a positive correlation with $\mathrm{N}$ mineralization [18].

\subsection{Plant species and shade tolerance scores}

We studied five coniferous species that vary in observed shade tolerance [2] and are common to the boreal and cold temperate forests of North America [3]. The species were: very intolerant Pinus banksiana Lamb., intolerant Pinus resinosa Ait., intermediate Pinus strobus L., tolerant Picea glauca (Moench) Voss. and very tolerant
Abies balsamea (L.) Mill. The observed shade tolerance classification was compared to the distribution of juveniles growing naturally in the field across a light gradient in Northern Minnesota [31]. The 10th percentile of the distribution of each species along the light gradient was used as an approximation of the lowest light levels tolerated by each species (Tab. II, see [30]). Scores are inversely related to the subjective assessments of shade tolerance rankings by North American foresters [3] and species rankings match exactly those of Lusk and Reich (2000). Light data for Pinus banksiana are not available.

One-year-old containerized seedlings were purchased from local nurseries. The seeds for these seedlings were collected from central Minnesota and northern Wisconsin forests (ca. $47^{\circ} \mathrm{N}$ ). The seedlings were planted and labeled in May 1993. Twelve individuals of each species, for a total of 1320 seedlings, were planted at approximately $30 \mathrm{~cm}$ spacing in a $1 \times 1 \mathrm{~m}$ subplot with a $0.5 \mathrm{~m}$ buffer that was 
randomized within the larger plots. Seedling total height before planting was measured in a subset of seedlings $(n=578)$.

\subsection{Seedling measurements}

In September 1996, after four growing seasons we hand excavated roots and shoots of four seedlings of each species at every experimental plot $(n=440)$. Since seedling excavations were time consuming, only the above-ground portion was collected for the remaining seedlings. Seedlings were divided into needles, stems and, if collected, roots. All plant material was dried in a forced air oven $\left(70{ }^{\circ} \mathrm{C}\right)$ and mass was measured. Projected area of fresh needles was determined with a video imaging system (AgVision, Decagon Devices, Inc., Pullman, WA, USA). Total nitrogen concentrations of dried and ground tissues were measured using the Kjeldahl Digestion assay (Research Analytical Laboratory, Department of Soil Science, University of Minnesota). For all seedlings, the following parameters were either measured or calculated when possible: length of terminal shoot $(\mathrm{cm})$, seedling height $(\mathrm{cm})$, relative main stem height ( $\ln$ [seedling height in 1996] $-\ln$ [seedling height in 1993].4 $\mathrm{yr}^{-1}$ ), total needle mass $(\mathrm{g})$, total stem mass $(\mathrm{g})$, total root mass $(\mathrm{g})$, total seedling needle area $\left(\mathrm{cm}^{2}\right)$, specific leaf area (SLA, $\mathrm{cm}^{2}$ of needle $\mathrm{g}^{-1}$ of needle), leaf area ratio (LAR, $\mathrm{cm}^{2}$ of needle $\mathrm{g}^{-1}$ of total plant mass), whole-plant nitrogen concentration ( $\mathrm{mg} \mathrm{N} \mathrm{g}^{-1}$ tissue).

\subsection{Data analysis}

Plots ( 11 for each control and trenched treatments for a total of 22) were considered experimental units. We analyzed for the effect of site on seedling performance but found no significant interaction among sites for canopy openness or trenching effects (data not shown). Hence, all trenching and light effects were analyzed for sites pooled. Differences in soil properties and light environments between trench and control plots were evaluated using two tailed $t$-tests.

To test effects of canopy openness and trenching on morphological and growth parameters, we used two-way mixed models where trenching ( 1 d.f.) and canopy openness ( 1 d.f.) were considered fixed nominal (trenched and control) and random (22 levels ranging from 3 to $11 \%$, see Tab. I) effects, respectively. We tested main effects and interactions on natural $\log (\ln )$-transformed growth parameters that were computed as the mean of all individuals (per species) that were present at the end of the experiment in each plot. Number of individuals per species per plot varied from 3 to 12 as a result of variation in survival.

We used an allometric approach to test the effects of canopy openness and trenching on biomass distribution parameter, by plotting the ln-transformed biomass of root, stem or leaves against the ln-transformed biomass of the whole plant [14, 37], and testing whether these slopes or intercepts varied with trenching or light level (akin to analysis of covariance). Since the relative proportion of biomass distributed to leaves, stems or roots is sensitive to the total mass of the plant, the allometric approach enables the separation of differences in biomass distribution due to differences in size from those due to true shifts in partitioning, and is "the only routine method of showing an effect of treatment on net partitioning" [15]. To employ this approach for light, it was necessary to divide all plots into different light categories. After considering the results of the ANOVA above, we grouped canopy openness plots in two categories: (1) Very Low $($ mean $=4 \%$ and range $=3.1$ to $5.5 \%)$ and $(2)$ Low $($ mean $=8 \%$ and range $=6.4$ to $11.1 \%$ )

To test for effects of canopy openness and trenching on seedling survival after four years, variables were categorized as described above and nominal logistic regression was used. All analyses were performed using JMP statistical software (SAS Institute, Cary, NC, USA).

\section{RESULTS}

\subsection{Seedling growth}

In general, trenching and light increased seedling growth of all species and these effects were generally additive since, with few exceptions, light $\times$ trenching effects were not significant (Tab. III). Over the continuous light levels chosen (i.e., 3 to $11 \%$ of open sky), across species, trenching increased whole-plant, needle and stem mass, leaf area and height, more consistently than light, whereas light more consistently increased leaf area ratio than did trenching (Tab. III, Figs. 1, 2 and 3).

Overall, shade intolerant and tolerant species responded similarly to trenching (Figs. 1 and 2). At a common average light environment of $6.6 \%$ canopy openness (least square means), trenching significantly increased plant height (relative and total main stem height) in all five species and mass for all species except Pinus resinosa (Tabs. IIIa, IIIb and IIIc). Except for Pinus resinosa (height increased by $5.3 \%$ and mass by $14.3 \%$ ), the proportional increases in height (range of 11.2 $14.5 \%$ ) and mass (range of 25.4-26.7\%) were similar among species, regardless of the larger differences in relative main stem height (range 14-32\%). In all species, increased mass was the result of similar and proportional increments of roots, stems, and needles (Fig. 1). Trenching significantly increased total needle and stem mass for all species except Pinus resinosa (Tabs. IIId and IIIe). Significant increments in total root mass were found only for the shade tolerant species, Abies balsamea and Picea glauca with an average increase of 11 and $20 \%$, respectively. In addition, trenching increased total needle area for all species except Pinus resinosa. Trenching did not affect specific leaf area, leaf area ratio or whole-plant nitrogen concentration except that nitrogen was marginally greater as a result of trenching in shade tolerant Abies balsamea $(P=0.072$, Fig. 2$)$.

The variation in light among the plots did not have as profound effect on seedling growth characteristics as trenching (Tab. III, Fig. 3). Height was positively related to light availability in Picea glauca, Pinus resinosa and Pinus banksiana (Fig. 3). Total biomass and all of its components increased with light in Picea glauca, as did stem mass in Pinus banksiana and root mass in Pinus resinosa (Tab. III). Specific leaf area decreased significantly with light only for Picea glauca while leaf area ratio decreased with light in all species except Pinus banksiana (Fig. 3, Tab. III). Light did not affect whole plant nitrogen concentration for any species (Tab. III).

\subsection{Effects of trenching and light on morphology and biomass distribution}

The proportion of biomass in roots, stems and needles was not affected by trenching in any species (Tab. IV). In essence, accounting for plant size (mass basis), there was no effect of trenching on biomass distribution patterns in any species (Fig. 4). Trenching increased total height and total nitrogen per plant at a common plant mass only for shade tolerant species Abies balsamea and Picea glauca (Fig. 4). In contrast to trenching, increased light from very low (3 to $5 \%$ ) to low light (6 to $11 \%$ ) decreased needle mass and increased root 
Table III. Analyses of variance by species for the effects of trenching and canopy openness on the mean values of the following variables: (a) relative main stem height, (b) ln-total plant height, (c) ln-total plant mass, (d) ln-total needle mass, (e) ln-total stem mass, (f) ln-total root mass, (g) ln-total plant leaf area, (h) specific leaf area (SLA) and (i) leaf area ratio (LAR). Species are listed left to right in order of observed shade tolerance in the field. Degrees of freedom for trenching, canopy openness and error term were 1, 1 and 19, respectively. The interaction term is trenching $\times$ canopy openness. Only $P$ values $<0.10$ are shown. Mean square values of the interaction term are shown only when significant.

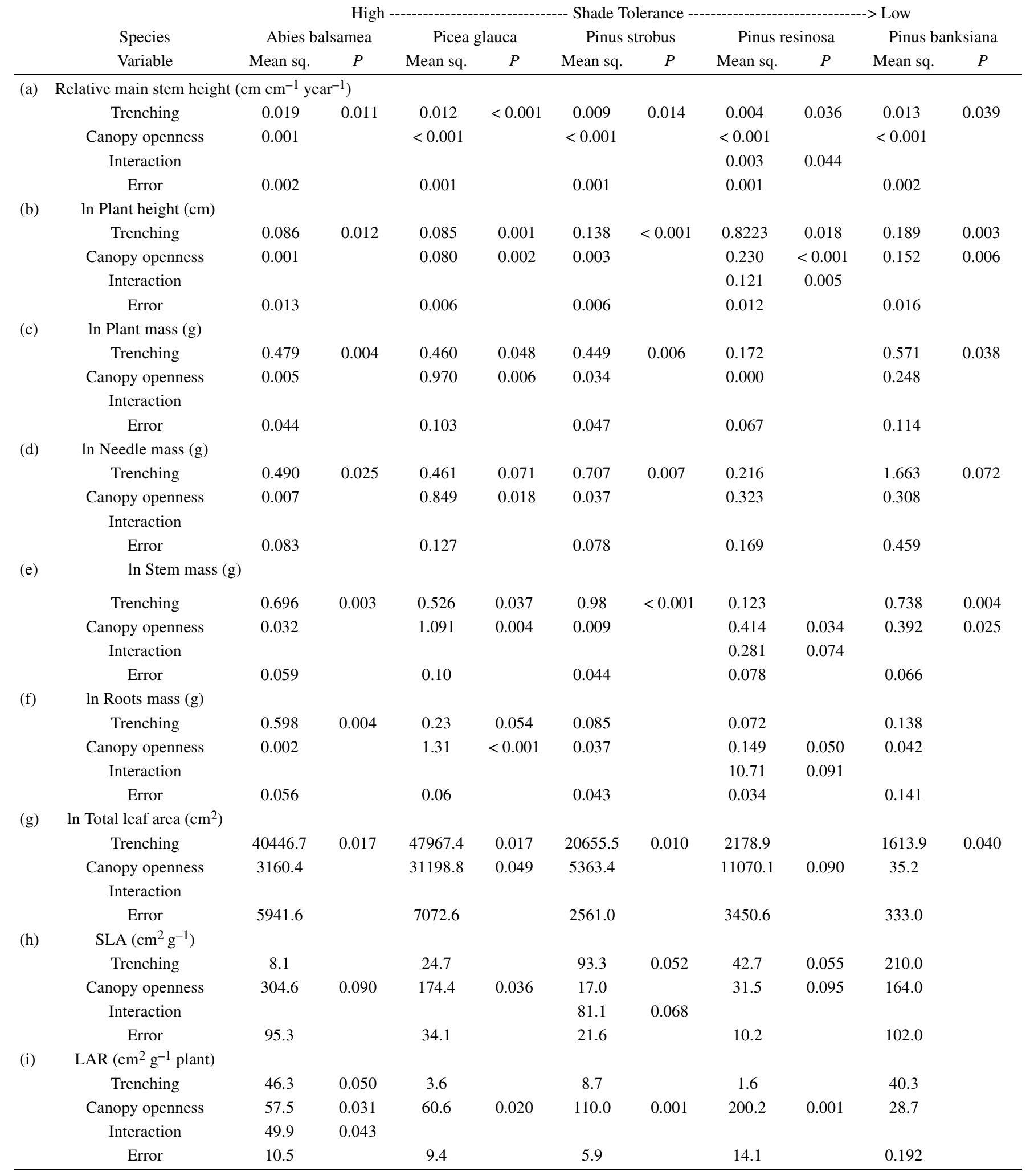



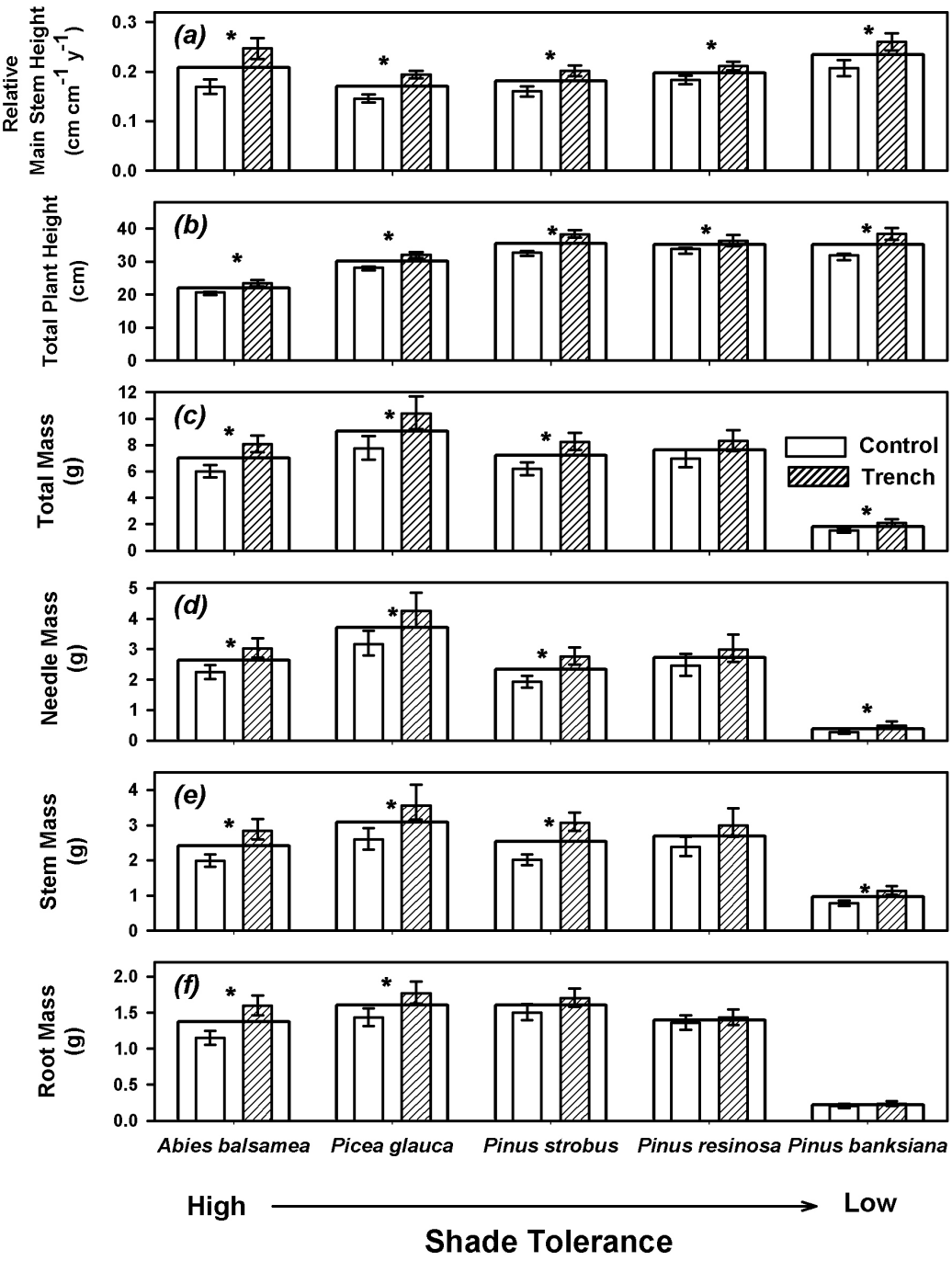

Figure 1. Effect of trenching on relative main stem height (panel $a$ ), total plant height (panel $b$ ), total seedling biomass (panel $c$ ), total needle mass (panel $d$ ), total stem mass (panel $e$ ) and total root mass (panel $f$ ) for five conifer species listed left to right in order of observed shade tolerance in the field (see Tab. III for ANOVA results). Values are least square adjusted means $( \pm \mathrm{SE})$ compared at common light environment (6.6 percent canopy openness). The background bar represents the pooled mean between trench and control plots. Asterisks illustrate significant differences between trenched and control plots (see Tab. III for ANOVA results). mass independent of plant mass for shade tolerant species Abies balsamea and Picea glauca (Tab. IV, Fig. 4).

\subsection{Seedling survival}

Percent survival after four years varied in relation with the species' reported shade tolerance rankings (Fig. 5). Mean seedling survival was $86 \%$ for Abies balsamea, $92 \%$ for Picea glauca, $87 \%$ for Pinus strobus, $77 \%$ for Pinus resinosa and $67 \%$ for Pinus banksiana. Trenching had a significant effect on seedling survival only for very shade intolerant Pinus banksiana (Likelihood ratio $=5.6, P>\chi^{2}=0.02$ ), which had higher survival in trenched $($ mean $=38.5 \%$, standard error $=$ $1.8)$ compared to control $($ mean $=32.0 \%$, standard error $=1.5)$ plots. Percent survival increased significantly (Likelihood ratio $=5.0, P>\chi^{2}=0.03$ ) with greater light availability in Picea glauca from $87.5 \%$ (standard error $=3.52$ ) in very low light to $95.2 \%$ (standard error $=2.9$ ) in low light. Two other species, Abies balsamea (Likelihood ratio $=3.3, P>\chi^{2}=0.07$ ) and Pinus strobus (Likelihood ratio $=3.0, P>\chi^{2}=0.08$ ) showed trends towards altered survival when comparing the two light classes. We did not find any significant trenching $x$ canopy openness interactions.

\section{DISCUSSION}

\subsection{Growth responses to trenching and light in deeply shaded environments}

In the deeply shaded understories of northern Wisconsin's temperate forests, trenching increased seedling mass and height independent of light level for both shade tolerant and intolerant species, supporting our hypothesis that increased soil resources will have a positive effect on whole-plant growth. For all species, mass increases due to trenching were the result of proportionally similar increases in roots, stems and needles. Thus, biomass distribution was not altered by increased soil resources, refuting our hypothesis that trenching will increase the proportional distribution towards leaves and stems and away from roots. Moreover, growth increased similarly as a result of trenching for all species regardless of their 

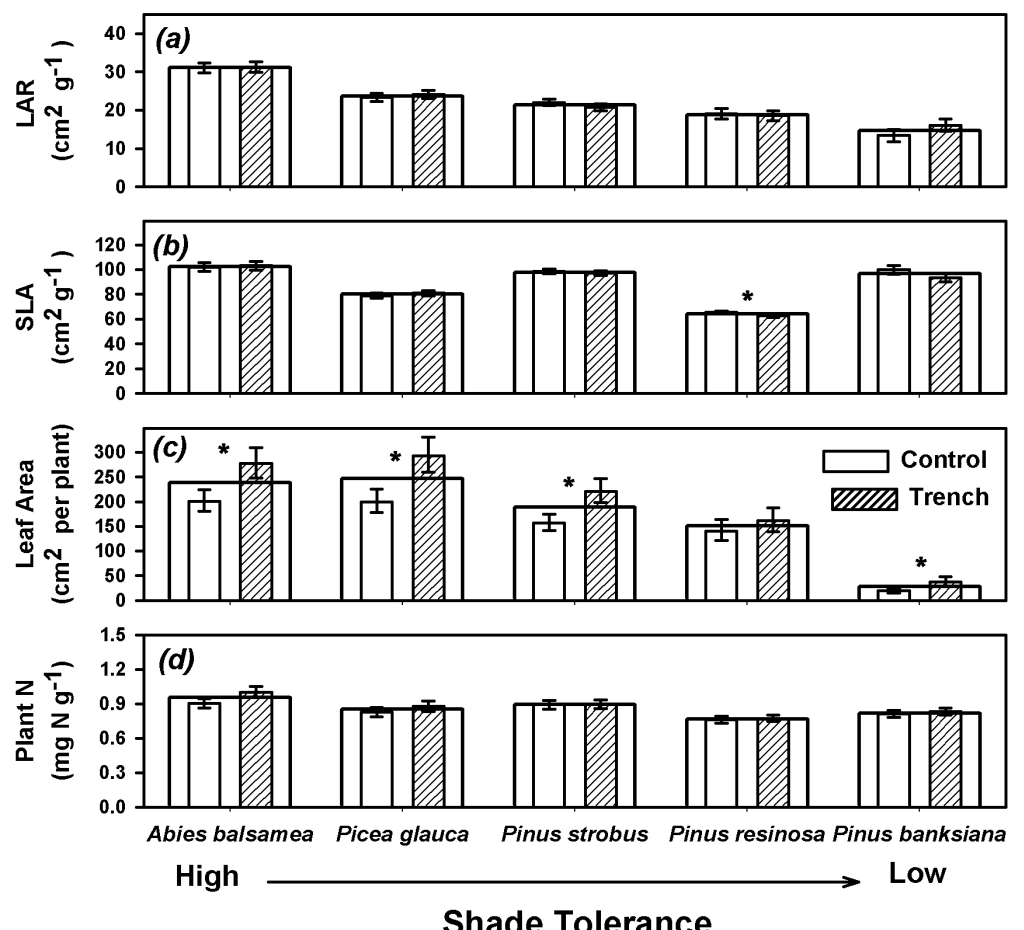

Shade Tolerance
Figure 2. Effect of trenching on leaf area ratio (LAR, panel $a$ ), specific leaf area (SLA, panel $b$ ), total leaf area (panel $c$ ) and whole-plant nitrogen concentration (panel $d$ ) for five conifer species listed left to right in order of observed shade tolerance in the field (see Tab. III for ANOVA results). Values are least square adjusted means ( \pm SE) compared at common light environments (6.6\% canopy openness). The background bar represents the pooled mean between trench and control plots. Asterisks illustrate significant differences between trenched and control plots (see Tab. III for ANOVA results). shade tolerance rankings, refuting the hypothesis that variation in shade tolerance will influence responses to trenching in the low light conditions of this study. Our results do not help to reconcile the current conflicting data. Some studies have shown that shade tolerant species tend to have greater growth rates in very low-light than intolerant species [23, 46] while, other studies have found that shade intolerant species grown in low-light environments have shown greater plasticity in biomass distribution to variation in soil resource availability (i.e., nitrogen, water) than for shade tolerant species [9, 29, 49, 50]. Thus, more plastic, shade intolerant species have shown greater growth responses to increased availability of soil resources than less plastic shade tolerant species.

Our results contradict previous experiments that have shown little or no variation in above-ground growth under low-light conditions in response to variation in soil resource availability (Dylis and Utkin in [45], [4, 9, 19, 20, 29, 46]). In contrast, positive growth responses to changes of soil fertility in deep shade have also been found in the trees Piceetum myrtillosum (Karpov in [46]), Liriodendron tulipifera growing in 3\% daylight [29], Acer saccharum growing in $1.5 \%$ to $4 \%$ daylight [47] and the herb Impatiens parviflora growing in 5\% daylight [34]. One study found positive responses in deep shade to variation in nutrient supply for shade tolerant but not intolerant species [50]. The variability of observed response to increased soil resources under deep shade could be in part the result of differences among studies in soil fertility [10], and/or result from incomplete data, i.e., no observations of belowground biomass $[9,35]$. Notably, our study was conducted on relatively low fertility sandy glacial outwash soils, which are the kind of sites that Coomes and Grubb (2000) predict would likely have severe below-ground limitations to seedling growth, even in low-light.
Increased light stimulated biomass growth only in the shade tolerant Picea glauca. Our results might either indicate that (1) the variation in light environments was not sufficient to cause detectable growth increases, although this range of light levels ( 3 to $11 \%$ canopy openness) has been previously reported to cause strong growth responses for many species both in field and in shade house experiments [24, 29, 46]; but see [4] or that (2) other sources of variation in this field study were large enough to mask any such response. However, height-to-mass ratios in the relative low-light conditions were different across species after averaging all light levels. Shade intolerant species were taller at a common mass than shade tolerant species, indicating that intolerant species etiolated in response to deep shade. Similar responses have been reported by Shirley (1945) working with the same species in northern Minnesota. Lowlight did increase leaf area ratio (LAR) in four out of the five species studied as has been reported for some of the same species in a greenhouse experiment [38] and in both studies plasticity in LAR did not vary among species as a function of variation in shade tolerance. Overall, our findings suggest that whole-plant growth of shade tolerant and intolerant species growing in low fertility conditions is limited by below-ground competition for resources at light levels that have been widely reported to be strongly limiting to growth [4, 24, 29, 38, 46].

\subsection{Biomass fraction in leaves, stems and roots: responses to trenching and light}

Increased soil resources (both water and nitrogen availability) as a result of trenching increased growth roughly similarly for all species while it had no effect on biomass distribution. This finding is contrary to the suggestion discussed by several authors that changes in biomass distribution to above-ground 


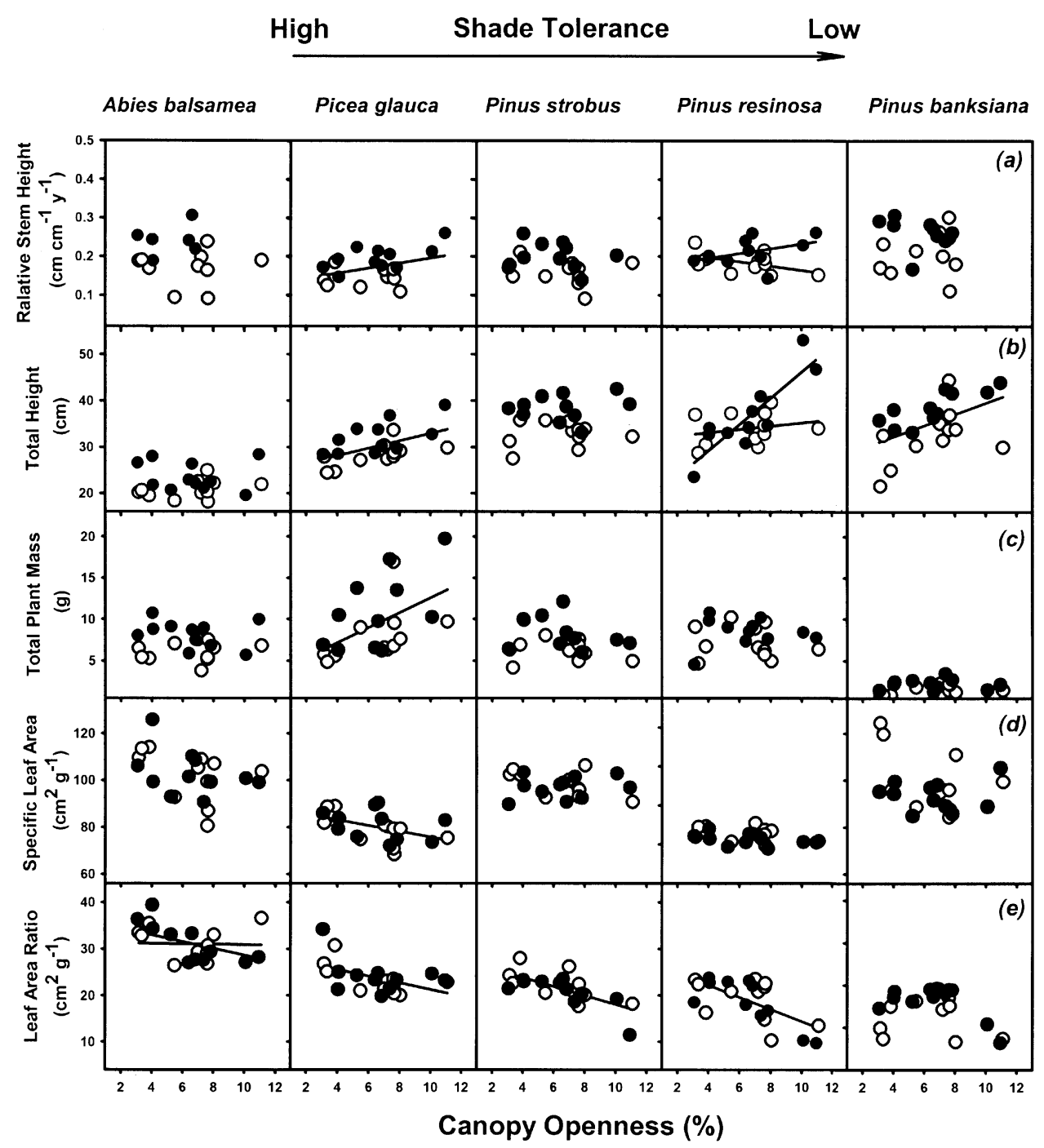

Figure 3. Effect of percent canopy oppenness on growth variables for seedlings in control (open circle) and trenched plots (closed circle). Growth variables are relative main stem height (panel $a$ ), total plant height (panel $b$ ), total plant mass (panel $c$ ), specific leaf area (SLA, panel $b$ ), and leaf area ratio (LAR, panel $a$ ), for five conifer species listed left to right in order of observed shade tolerance in the field. One line indicates that the response changes significant with variation in percent canopy openness. Two lines indicate the presence of canopy openness $\times$ trenching interaction (see Tab. III for ANOVA results). Values are means of either control or trench plots.

biomass are a primary effect of trenching (Karpov in [45], [9, 29, 34-36]). However, some authors have proposed that if plants are to increase their ability to acquire limiting resources then changes in biomass distribution are of little adaptive significance compared to morphological changes such as surface area or length of tissues [1, 28, 37]. Moreover, it is possible that trenching increases growth by increasing physiological activity (i.e., photosynthesis) rather than by altering biomass distribution and that the increase in physiological activity is similar for all species.

\subsection{Seedling survival}

Our hypothesis about differential survival responses to increased soil resources of tolerant and intolerant species was only weakly supported. The very intolerant Pinus banksiana showed a significant increase in survival as a result of trenching, as predicted, but the other intolerant pine species did not. Some other, but not all [46], studies have also shown that survival in low-light environments may increase with increases in soil fertility in some species or cases [25, 50]. Given their increased growth, we cannot reconcile the overall (all species) lack of survival response to increased soil resources, contrary to our prediction that trenching will have a positive effect on survival.

In general, all of the species in our study showed high levels of survival after four growing seasons (over 60\%) regardless of light environment and trenching treatment. Mean seedling survival followed the species reported shade tolerance rankings, suggesting that survival was more closely linked to the overall level of light than soil resources. 
Table IV. Analyses of covariance by species for the effects of trenching and low light environments on biomass distribution using ln-wholeplant mass as a covariate on the following variables: (a) relative main stem height, (b) ln-total plant height, (c) ln-total needle mass, (d) ln-total stem mass, (e) ln-total root mass and (f) ln-whole-plant nitrogen. Degrees of freedom for trenching, canopy openness and error term were 1, 1 and 80, respectively. Seedlings were group into two categories of percent canopy openness: low (3.1 to 5.5\%) and high (6.4 to $11.1 \%$ ). Species are listed left to right in order of observed shade tolerance in the field. The interaction term is trenching $\times$ canopy openness. Only $P$ values $<0.10$ are shown. Mean square values of the interaction term are shown only when significant.

\begin{tabular}{|c|c|c|c|c|c|c|c|c|c|c|c|}
\hline & \multirow{2}{*}{$\begin{array}{l}\text { Species } \\
\text { Variable }\end{array}$} & \multicolumn{2}{|c|}{$\begin{array}{l}\text { High } \\
\text { Abies balsamea }\end{array}$} & \multicolumn{6}{|c|}{-- Shade Tolerance ------------------------------> Low } & & ksiana \\
\hline & & mean sq. & & mean sq. & $P$ & mean sq. & $P$ & Mean sq. & $P$ & mean sq. & $P$ \\
\hline \multirow[t]{6}{*}{ (a) } & Relative main stem heig & $\mathrm{cm} \mathrm{cm}^{-1} \mathrm{y}$ & $\left.\operatorname{ar}^{-1}\right)$ & & & & & & & & \\
\hline & In plant mass & 0.014 & 0.0652 & 0.118 & $<0.0001$ & $<0.001$ & & 0.008 & 0.0134 & 0.038 & 0.0013 \\
\hline & Trenching & 0.001 & & 0.131 & $<0.0001$ & 0.002 & & 0.009 & 0.0089 & 0.001 & \\
\hline & Canopy openness & $<0.001$ & & 0.001 & & $<0.001$ & & 0.003 & 0.1014 & $<0.001$ & \\
\hline & Interaction & & & & & 0.006 & 0.0984 & & & & \\
\hline & Error & & & & & & & & & & \\
\hline \multirow[t]{6}{*}{ (b) } & ln Plant height $(\mathrm{cm})$ & & & & & & & & & & \\
\hline & ln Plant mass (g) & 0.816 & $<0.001$ & 0.955 & $<0.001$ & 0.806 & $<0.001$ & 0.824 & $<0.001$ & 1.05 & $<0.001$ \\
\hline & Trenching & 0.146 & 0.01 & 0.094 & 0.032 & 0.002 & & 0.003 & & 0.046 & \\
\hline & Canopy openness & 0.002 & & 0.065 & 0.076 & 0.001 & & 0.239 & 0.001 & 0.235 & 0.004 \\
\hline & Interaction & & & & & & & & & & \\
\hline & Error & 0.021 & & 0.020 & & 0.011 & & 0.02 & & 0.026 & \\
\hline \multirow[t]{6}{*}{ (c) } & ln Needle mass (g) & & & & & & & & & & \\
\hline & ln Plant mass (g) & 11.70 & $<0.001$ & 24.71 & $<0.001$ & 9.276 & $<0.001$ & 11.01 & $<0.001$ & 30.82 & $<0.001$ \\
\hline & Trenching & 0.047 & 0.056 & 0.001 & & 0.001 & & 0.009 & & 0.081 & \\
\hline & Canopy openness & 0.15 & $<0.001$ & 0.083 & 0.001 & 0.011 & & 0.941 & 0.001 & 0.025 & \\
\hline & Interaction & & & & & & & & & & \\
\hline & Error & 0.013 & & 0.007 & & 0.021 & & 0.082 & & 0.091 & \\
\hline \multirow[t]{6}{*}{ (d) } & ln Stem mass (g) & & & & & & & & & & \\
\hline & ln Plant mass (g) & 11.759 & $<0.001$ & 25.55 & $<0.001$ & 8.677 & $<0.001$ & 8.934 & $<0.001$ & 10.544 & $<0.001$ \\
\hline & Trenching & 0.014 & & 0.001 & & 0.014 & & 0.002 & & 0.011 & \\
\hline & Canopy openness & 0.033 & 0.022 & 0.00 & & 0.012 & & 0.323 & 0.001 & 0.046 & \\
\hline & Interaction & 0.036 & 0.018 & 0.043 & 0.044 & & & & & & \\
\hline & Error & 0.006 & & 0.01 & & 0.012 & & 0.0294 & & 0.028 & \\
\hline \multirow[t]{6}{*}{ (e) } & ln Roots mass (g) & & & & & & & & & & \\
\hline & ln Plant mass (g) & 8.786 & $<0.001$ & 12.796 & $<0.001$ & 4.532 & $<0.001$ & 5.602 & $<0.001$ & 9.784 & $<0.001$ \\
\hline & Trenching & 0.061 & & 0.028 & & 0.046 & & 0.041 & & 0.168 & \\
\hline & Canopy openness & 0.188 & & 0.411 & 0.011 & 0.043 & & 0.164 & 0.098 & 1.141 & 0.004 \\
\hline & Interaction & & & & & & & & & & \\
\hline & Error & 0.066 & & 0.061 & & 0.045 & & 0.056 & & 0.127 & \\
\hline \multirow[t]{6}{*}{ (f) } & $\ln N\left(\right.$ mg plant $\left.^{-1}\right)$ & & & & & & & & & & \\
\hline & ln Plant mass (g) & 9.91 & $<0.001$ & 16.589 & $<0.001$ & 7.528 & $<0.001$ & 9.316 & $<0.001$ & 14.189 & $<0.001$ \\
\hline & Trenching & 0.153 & 0.001 & 0.089 & 0.021 & 0.003 & & 0.003 & & 0.001 & \\
\hline & Canopy openness & 0.093 & 0.008 & 0.001 & & 0.009 & & 0.001 & & 0.000 & \\
\hline & Interaction & 0.131 & 0.002 & & & & & 0.085 & 0.004 & 0.047 & 0.058 \\
\hline & Error & 0.013 & & 0.016 & & 0.013 & & 0.01 & & 0.013 & \\
\hline
\end{tabular}




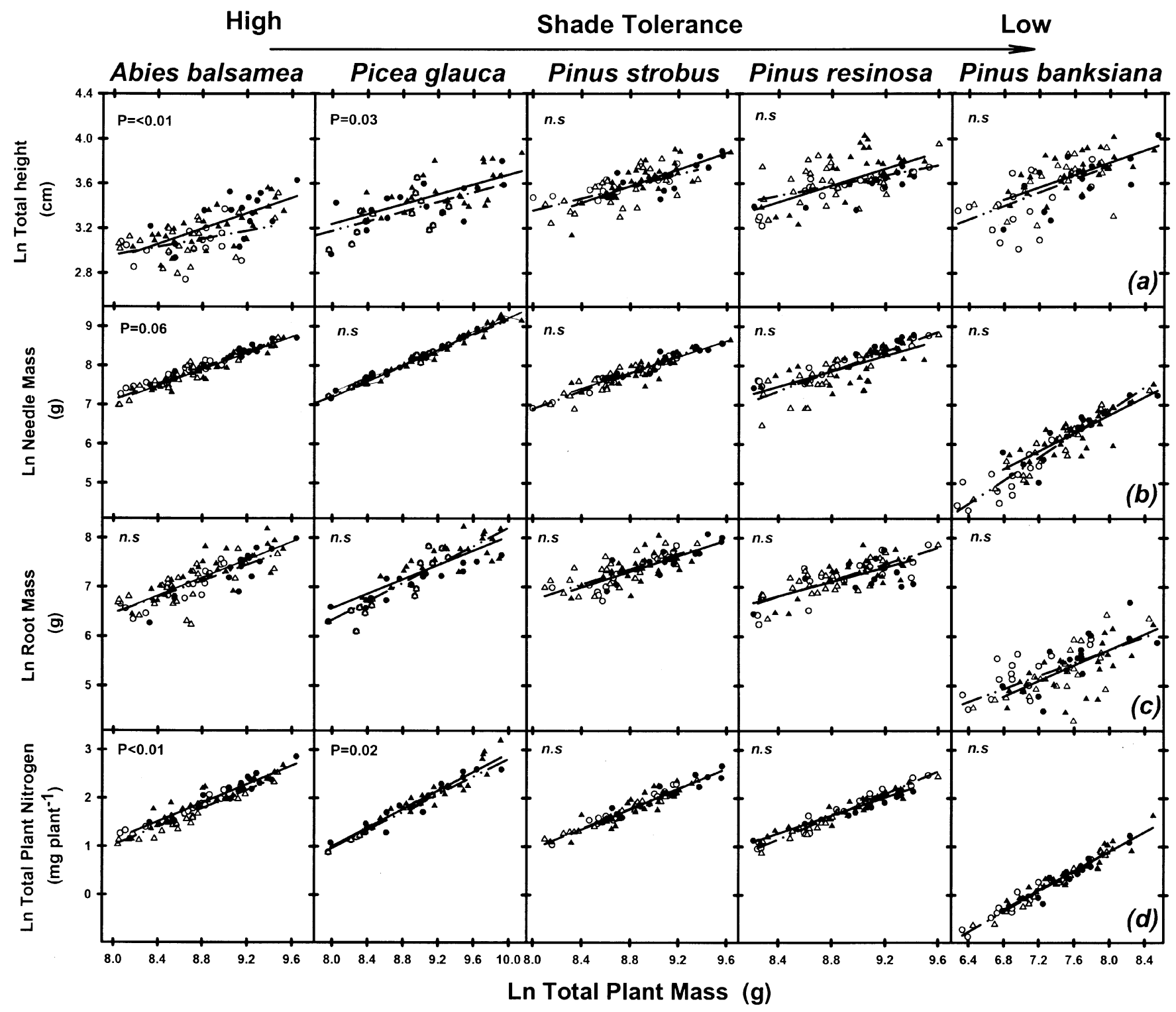

Figure 4. Relationship between total plant height (panel $a$ ), total needle mass (panel $b$ ), total root mass (panel $c$ ), total plant nitrogen (panel $d$ ) and total plant mass of seedlings grown in control (solid line) and trenched (dotted line) plots. Conifer species are arranged left to right in order of observed shade tolerance in the field. Light environments were pooled for the regression lines and were divided into very low (3.1 to 5.5) and low (6.4 to 11.1) percent canopy openness. Values are the means of control very low-light plots (open circle), control low-light plots (open triangle), trench very low-light plots (closed circle) and trench low-light plots (closed triangle). The full ANCOVA values are presented in Table IV.

\subsection{Implications for community dynamics}

Natural communities are composed of species that are assumed to be limited by different ranges of combinations of resources and these interspecific differences, could, in part, be driven by variation in biomass distribution patterns [8] Consequently, interspecific variation in biomass distribution patterns and in the plasticity of these patterns to variation in resource availability may be important mechanisms underlying the pattern and dynamics of forested communities. These observations are among the pillars of the multiple resource limitation theory, which suggests that plants adjust to situations of resource imbalance by allocating more biomass to the tissues that acquire the most strongly limiting resources $[8,16$, $17,42]$. Although we found large differences among species in survival, and morphology (e.g., LAR was greater for shade tolerant than intolerant species), our study species differed little in their growth and biomass distribution responses to increased soil resource availability suggesting that variation in these responses is not an important component of adaptation to low-light forest understories, at least not across the range 


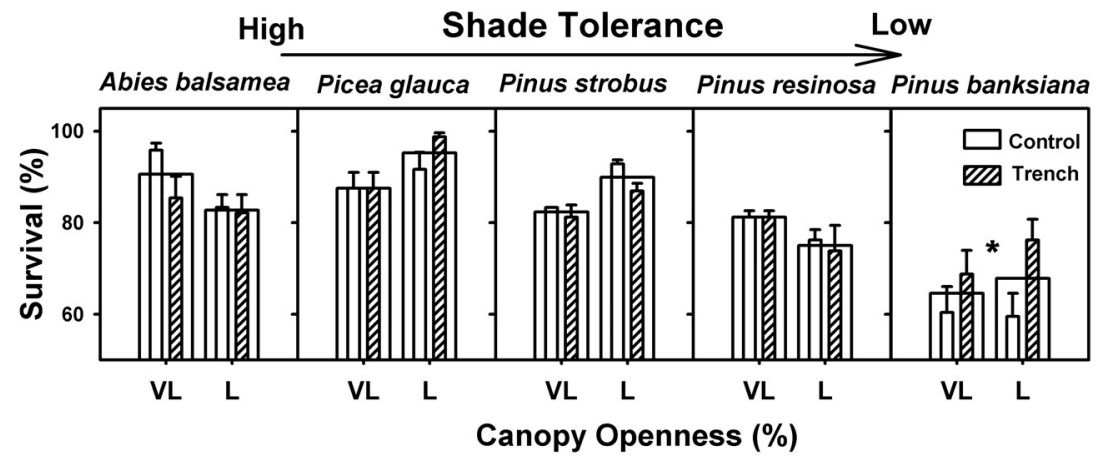

Figure 5. Trenching and canopy openness effects on percent seedling survival. Conifer species are arranged according to their shade tolerance rankings. Light environments were divided in very low $(\mathrm{VL}=3.1$ to 5.5$)$ and low $(\mathrm{L}=6.4$ to 11.1$)$ percent canopy openness. Percent survival was calculated based on the number of seedlings alive at the end of four growing seasons for each treatment combination. The background bar represents the pooled mean percent survival for all light environment classes within control and trench treatment. Asterisk illustrate significant differences between trenched and control plots. of light and soil resource availability present in our study (consistent with [47], for Acer saccharum). Our study also shows that below-ground resources do matter to plant growth even for plants growing in deep shade, and regardless of their shade tolerance rankings.

Acknowledgments: This research was part of a $\mathrm{Ph} . \mathrm{D}$. dissertation presented to the University of Minnesota, Department of Forest Resources. Funding was provided by the Wilderness Research Foundation, National Science Foundation (USA), the F.B. Hubachek Sr. Endowment at the University of Minnesota, and the Provost's Office at Swarthmore College. Thanks are due to the late Tom Frost and the Trout Lake station staff at the University of Wisconsin for their invaluable logistical support, to Cleo $\mathrm{C}$ Lajzerowicz for providing help in the field, to Elizabeth M. Svenson for editorial comments, and to the many work-study undergraduates at the University of Minnesota. Michael F. Tobin was instrumental during the set-up of the project. We thank David Hibbs and an anonymous reviewer for their comments to improve the manuscript.

\section{REFERENCES}

[1] Aerts R., Chapin III F.S., Mineral nutrition of wild plants revisited: a re-evaluation of processes and patterns, Adv. Ecol. Res. 30 (2000) $1-67$.

[2] Baker F.S., A revised tolerance table, J. For. 47 (1949) 179-181.

[3] Barnes B.V., Wagner W.H., Michigan tress: a guide to the trees of Michigan and the Great Lakes Region, The University of Michigan Press, Ann Arbor, Michigan, 1996.

[4] Canham C.D., Berkowitz A.R., Kelly V.R., Lovett G.M., Ollinger S.V., Schnurr J., Biomass allocation and multiple resource limitation in tree seedlings, Can. J. For. Res. 26 (1996) 1521-1530.

[5] Canham C.D., Finzi A.C., Pacala S.W., Burbank D.H., Causes and consequences of resource heterogeneity in forests - interspecific variation in light transmission by canopy trees, Can. J. For. Res. 24 (1994) 337-349.

[6] Casper B.B., Jackson R.B., Plant competition underground, Annu. Rev. Ecol. Syst. 28 (1997) 545-570.

[7] Chapin III F.S., The mineral nutrition of wild plants, Annu. Rev. Ecol. Syst. 11 (1980) 233-260.

[8] Chapin III F.S., Bloom A.J., Field C.B., Waring R.H., Plant responses to multiple environmental factors, Bioscience 37 (1987) 49-57.

[9] Coomes D.A., Grubb P.J., Responses of juvenile trees to aboveand below-ground competition in nutrient-starved Amazonian rain forest, Ecology 79 (1998) 768-782.
[10] Coomes D.A., Grubb P.J., Impacts of root competition in forests and woodlands: a theoretical framework and review of experiments, Ecol. Monogr. 70 (2000) 171-207.

[11] Craib I.J., Some aspects of soil-moisture in the forest, Yale Univ. School, For. Bull. 25 (1929).

[12] Dillenberg L.R., Whigham D.F., Teramura A.H., Forseth I.N., Effects of belowground and aboveground competition from the vines Lonicera japonica and Parthenocissus quinquefolia on the growth of the tree host Liquidambar styraciflua, Oecologia 93 (1993) 48-54.

[13] Ellison L., Houston W.R., Production of herbaceous vegetation in openings and under canopies of western aspen, Ecology 39 (1958) 337-345.

[14] Evans G.C. The quantitative analysis of plant growth, University of California Press, California, 1972.

[15] Farrar J.F., Gunn S., Allocation: allometry acclimation and alchemy?, in: Lambers H., Poorter H., Van Vuuren M.M.I. (Eds.), Inherent Variation in Plant Growth. Physiological Mechanisms and Ecological Consequences. Bacckhuys Publishers, Leiden, The Netherlands, 1998, pp. 183-198.

[16] Givnish T.J., On the economy of plant form and function, Cambridge University Press, Cambridge, England, 1986.

[17] Gleeson S.K., Tilman D., Plant allocation and the multiple limitation hypothesis, Am. Nat. 139 (1992) 1322-1343.

[18] Grigal D.F., Homann P.S., Nitrogen mineralization, groundwater dynamics, and forest growth on a Minnesota outwash landscape, Biogeochemistry 27 (1994) 171-185.

[19] Grubb P.J., Root competition in soils of different fertility: a paradox resolved?, Phytocoenologia 24 (1994) 495-505.

[20] Grubb P.J., Lee W.G., Kollmann J., Wilson J.B., Interactions of irradiance and soil nutrient supply on growth of seedlings of ten European tall-shrub species and Fagus sylvatica, J. Eco. 84 (1996) $827-840$.

[21] Harmer R., Alexander I.J., Effects of root exclusion on nitrogen transformation and decomposition processes in spruce humus, in Atkinson D., Read D.J., Usher M.B. (Eds.), Ecological Interactions in Soil: Plants, Microbes and Animals, Special Publication of The British Ecological Number 4, Blackwell Scientific, Oxford, 1985, pp. 267-278.

[22] Hart S.C., Sollins P., Soil carbon and nitrogen pools and processes in an old-growth conifer forest 13 years after trenching, Can. J. For. Res. 28 (1998) 1261-1265.

[23] King D.A., Influence of light level on the growth and morphology of saplings in a Panamanian forest, Am. J. Bot. 81 (1994) 948-957.

[24] Kitajima K., Relative importance of photosynthetic traits and allocation patterns as correlates of seedling shade tolerance of 13 tropical trees, Oecologia 98 (1994) 419-428. 
[25] Kobe R.K., Pacala S.W., Silander J.A., Canham C.D., Juvenile tree survivorship as a component of shade tolerance, Ecol. Appl. 5 (1995) 517-532.

[26] Kobe R.K., Interspecific variation in sapling mortality and growth predicts geographic variation in forest composition, Ecol. Monogr. 66 (1996) 181-201.

[27] Korstian C.F., Coile T.S., Plant competition in forest stands, Duke Univ. School, For. Bull. 3 (1938) 1-125.

[28] Lambers H., Poorter H., Inherent variation in growth rate between higher plants: a search for physiological causes and ecological consequences, Adv. Ecol. Res. 22 (1992) 187-261.

[29] Latham R.E., Co-occurring tree species change rank in seedling performance with resources varied experimentally, Ecology 73 (1992) 2129-2144.

[30] Lusk C.H., Reich P.B., Relationships of leaf dark respiration with light environment and tissue nitrogen content in juveniles of 11 cold-temperate tree species, Oecologia 123 (2000) 318-329.

[31] Machado J.-L., The Role of Resource Availability in the Growth, Distribution, Survival, and Physiology of Cold Temperate Tree Species. Ph.D. thesis, University of Minnesota, 1999.

[32] Machado J.-L., Reich P.B., Evaluation of several measures of canopy openness as predictors of photosynthetic photon flux density in deeply shaded conifer-dominated forest understory, Can J. For. Res. 29 (1999) 1438-1444.

[33] Pacala S.W., Canham C.D., Silander J.A., Kobe R.K., Sapling growth as a function of resources in a north temperate forest, Can. J. For. Res. 24 (1994) 2172-2183.

[34] Peace W.J., Grubb P.J., Interaction of light and mineral nutrients supply in the growth of Impatients parviflora, New Phytol. 90 (1982) $127-150$.

[35] Putz F.E., Canham C.D., Mechanisms of arrested succession in shrublands: root and shoot competition between shrubs and tree seedlings, For. Ecol. Manag. 49 (1992) 267-275.

[36] Putz F.E., Reduction of root competition increases growth of slash pine seedlings on a cutover site in Florida, South J. Appl. For. 16 (1992) 193-197.

[37] Reich P.B., Root-shoot relationships: optimality in biomass allocation or the "Emperor's New Clothes?", in: Waisel Y., Kafkafi U. (Eds.), Plant roots: the Hidden Half, Marcel Dekker, Inc. New York, 2002, pp. 205-220.
[38] Reich P.B., Tjoelker M.G., Walters M.B., Vanderklein D.W., Buschena C., Close association of RGR, leaf and root morphology, seed mass and shade tolerance in seedlings of nine boreal tree species grown in high and low light, Funct. Eco. 12 (1998) 327-338.

[39] Sadanandan Nambiar E.K., Sands R., Competition for water and nutrients in forests, Can. J. For. Res. 23 (1993) 1955-1968.

[40] Shirley H.L., Reproduction of upland conifers in the Lake States as affected by root competition and light, Am. Midl. Nat. 33 (1945) 537-612.

[41] Silver W.L., Vogt K.A., Fine root dynamics following single and multiple disturbances in a subtropical wet forest ecosystem, J. Ecol. 81 (1993) 729-738.

[42] Tilman D., Plant strategies and the dynamics and structure of plant communities, Princeton University Press, Princeton, New Jersey, 1988.

[43] Tilman D., Constraints and tradeoffs: toward a predictive theory of competition and succession, Oikos 58 (1990) 3-15.

[44] Vitousek P.M., Gosz J.R., Grier C.C., Melillo J.M., Reiners W.A., A comparative analysis of potential nitrification and nitrate mobility in forest ecosystems, Ecol. Monogr. 52 (1982) 155-177.

[45] Walter H., Breckle S.W., Ecological systems of the biosphere. I. Ecological principles in global perspectives, Springer-Verlag, Berlin, Germany, 1985.

[46] Walters M.B., Reich P.B., Are shade tolerance, survival, and growth linked? Low light and, nitrogen effects on hardwood seedlings, Ecology 77 (1996) 841-853.

[47] Walters M.B., Reich P.B., Growth of Acer saccharum seedlings in deeply shaded understories of northern Wisconsin - effects of nitrogen and water availability, Can. J. For. Res. 27 (1997) 237-247.

[48] Walters M.B., Reich P.B., Low-light carbon balance and shade tolerance in the seedlings of woody plants: do winter deciduous and broad-leaved evergreen species differ?, New Phytol. 143 (1999) 143-154.

[49] Walters M.B., Reich P.B., Tradeoffs in low-light $\mathrm{CO}_{2}$ exchange: a component of variation in shade tolerance among cold temperate tree seedlings, Funct. Ecol. 14 (2000) 155-165.

[50] Walters M.B., Reich P.B., Seed size, nitrogen supply and growth rate affect tree seedling survival in deep shade, Ecology 81 (2000) $1887-1901$. 